\title{
Heavy Metals Safety of Ready-To-Eat (RTE) Vegetables Salads (A review)
}

\author{
${ }^{1}$ Garba, M., ${ }^{1}$ Dandago, M. A., ${ }^{2}$ Igwe, E. C. and ${ }^{3}$ Salami, K. D \\ ${ }^{1}$ Department of Food Science and Technology, \\ Kano University of Science and Technology Wudil, \\ Kano State, Nigeria \\ ${ }^{2}$ Department of Food Science and Technology, \\ Nnamdi Azikwe University Awka, \\ Anambra State, Nigeria \\ ${ }^{3}$ Department Forestry and Wildlife Management, \\ Federal University Dutse, \\ Jigawa State Nigeria
}

Email: maimunagarba2@gmail.com

\begin{abstract}
Vegetables are one of the classes of foods that importantly contribute to the whole health and wellbeing of its consumers. It benefits the human body with important nutrients and help in reducing kind of chronic diseases. Ready-to-eat (RTE) foods are generally becoming more popular even in the developing world due to change in lifestyles. One of the most usually RTE food consumed in the northern Nigeria is road side salad that is arranged with vegetables usually lettuce (Lactuca sativa L.), cabbage (Brassica oleracea var. capitata) or Cress (Lepidium sativum Linn.) as the main components with the addition of tomato, onion and carrot. However, the consumption of RTE foods promote severe safety threats as vegetables prove well-known trace element and heavy metals (HMs) some of which are essential for good health while some are toxic. HMs include lead $(\mathrm{Pb})$, cadmium $(\mathrm{Cd})$, zinc $(\mathrm{Zn})$, mercury $(\mathrm{Hg})$, arsenic (As), silver $(\mathrm{Ag})$, chromium $(\mathrm{Cr})$, copper $(\mathrm{Cu})$, iron ( $\mathrm{Fe})$, and platinum (Pt). Different sources through which vegetables can be contaminated with these HMs are natural sources, agricultural sources, industrial sources, domestic effluent, atmospheric sources and other sources. Ingestion of vegetables containing HMs is one of the major means in which these elements enter human body. Once entered, HMs is dumped in bone and fat tissues, overlapping noble minerals. Slowly released into the body, HMs can cause an array of diseases. Thus, the essence of this study is to review the safety of the RTE vegetable salads, assessing the contamination level of some dangerous HMs present. As RTE salads can be contaminated with different types HMs that makes them unsafe for human consumption, regulatory bodies should design a periodic workshop training for RTE foods hawkers to help fix the problems and enhance the effectiveness of RTE vegetables salads preparation. Public awareness on the serious health risk associated with mishandled prepared insignificantly processed RTE foods most especially vegetable salads should be considered.
\end{abstract}

Keywords: contamination, heavy metals, ready-to-eat salads, vegetables. 


\section{INTRODUCTION}

Universally, green vegetable production contributes immensely to the food market. Farmers are motivated to produce them throughout the year due to the high demand and health benefits derived from the consumption of fresh vegetables. Farmers are inspired to produce vegetables due to the high demand and health benefits acquire from the consumption annually (Amissah-reynolds et al., 2020).

Leafy vegetables are vital component of a healthy diet, providing important phyto-nutrients vitamins and minerals. Their consumption is encouraged in many countries by government health agencies to protect against a range of illnesses such as cancer and cardiovascular diseases and therefore, there has been a continued escalate in the consumption of fresh produce as a result of efforts to promote better nutrition (Castro-rosas et al., 2012).

The demand for vegetables has increased explosively. The main driving force for this market growth is the increasing consumer demand for fresh, healthy, convenient and additive-free prepared products (Giusti et al., 2010; Kim et al., 2015; Gill et al., 2017). Fresh produce is commonly wide-reaching because it is recognized as vital source of nutrients, vitamins and fiber for humans (Gil et al., 2017).

Leafy salad vegetables are considered foods that can be taken immediately at the point of sale without advance treatment. RTE-salads constitute a suitable and convenient meal for today's lifestyles because they need no cooking. As well as being considered low-calorie food, they are rich in fiber and provide a great variety of vitamins, minerals, and other phytochemicals (Caponigro et al., 2010; Tatsika et al., 2019).

The consumption of vegetable is greatly increase based on the evidence of medical and nutritional benefits in Nigeria (Ajayeoba et al., 2015). As food safety continues to be globally public health issue epidemiological studies have shown increase in the number of producerelated foodborne sicknesses more than thirty years(Varzakas \&Arvanitoyannis, 2008).

Vegetables provide renowned trace elements and heavy metals (HMs) which are important for good health if they come from an organic. In contrast, if they come from an inorganic or metallic source, they become toxic (Bagdatlioglu \& Nergiz, 2010) For the benefit of human health, the concentrations of heavy metals in vegetables, which have a great role in human nutrition, should not exceed the permitted limits. Thus, it is vital to regularly monitor the accumulation of HMs in agricultural lands. Green vegetables have a greater ability to accumulate HMs compared to grains and other vegetables, making them more dominant in humans' exposure to HMs (Leblebici \& Kar, 2020). Vegetables ingestion is one the major ways in which these heavy metals enter the human body. Once they entered, HMs is dumped in bone and fat tissues, overlapping noble minerals causing a decrease of immunological defenses.

Slowly released into the body, HMs can cause an array of diseases and disabilities associated with malnutrition and a high prevalence of upper gastrointestinal cancer (Guerra et al., 2012). Cadmium and lead are the most toxic elements for man. In terms of environmental concentration, $\mathrm{Pb}$ is the $\mathrm{HM}$ closest to the level in which toxic signs manifest than any other substance. Others elements such as $\mathrm{Cr}$, $\mathrm{Co}$ and $\mathrm{Ni}$, although essential for human, at concentrations higher than those recommended, may cause metabolic disorders (Guerra et al., 2012).

This research reviewed papers focused on heavy metals and provide information on HMs sources and contaminations. 


\section{Ready-to-eat (RTE) salads}

Salad produces mainly from mixture of raw vegetables (Sabbithi et al., 2014; Souza, 2013). RTE Salads are fresh vegetables which entail minimal processing which include washing, cutting into desired shapes and sizes with knives or other shredding utensils and usually served with other foods (Abakari et al., 2018). RTE salads are a suitable way to ensure intake of vegetables (Mogren et al., 2018). During combining of some GLVs with tomatoes, onions, carrots and cucumbers, a colorful, healthy salad can be created (Settaluri et al., 2015). Globally, salad vegetables are considered as a main source of nutrients for people including vitamins, minerals, proteins and relevant nutritional components for the proper functioning of the human body and particularly as sources of cancer fighting agents for the skin. Recent studies have established that consumption of salad vegetables can prevent heart diseases and skin cancers (Abakari et al., 2018).

\section{Increased consumption of RTE salads}

Intake of vegetables has increased over the last ten years (Mogren et al., 2018) mainly due to the fact that, today's consumers are more aware of the nutritional and health benefits of fresh produces ( Heaton and Jones, 2008; Tirpanalan et al., 2011). The positive change in consumption of these types of products has increased the universal demand and the need for annual availability to consumers (Gil et al., 2015).

Salads well known in third world countries over the years because of the ease of consumption, palatability and also for increased awareness about the relations between health status and consumption of vegetables and changing lifestyle patterns (Abakari et al., 2018; Ahmad et al., 2018).

Vegetable salads are important part of a nutritious and healthy diet globally, they also guarantee food security for all population and also serves as a source of income for hawkers (Abakari et al., 2018).

\section{Vegetables Used for RTE Salads}

\section{Lettuce (Lactuca sativa L.)}

Globally, lettuce is one of the most widely consumed vegetables, but its nutritional value has been underrated. It known with low calories and a good source of fiber, iron, folate, and vitamin C. Lettuce is also a good source of various other health-beneficial bioactive compounds (Kim et al., 2016). Lettuce comes in a variety of colours, sizes and shapes and because of this diversity lettuce can be grouped by their types. It has six main types based upon leaf shape, size, texture, head formation, and stem type. They are (1) crisp head lettuce (var. capitata L. nidus jaggeri Helm), (2) butterhead lettuce (var. capitata L. nidus tenerrima Helm), (3) romaine or cos lettuce (var. longifolia Lam., var. romana Hort. in Bailey), (4) leaf or cutting lettuce (var. acephala Alef., syn. var. secalina Alef., syn. var. crispa L.), (5) stem or stalk (Asparagus) lettuce (var. angustana Irish ex Bremer, syn. var. asparagina Bailey, syn. L. angustana Hort. In Vilm.), and (6) Latin lettuce (no scientific name) (Kim et al., 2016). Dark lettuces are rich in vitamins $\mathrm{A}, \mathrm{C}$ and $\mathrm{K}$; and eating them regularly improves eyesight, bone health, skin elasticity and also assist in normal blood clotting. Dark green lettuces include romaine, green leaf, arugula and butter head (Dan et al., 2014; Kim et al., 2016). These nutrientdense leaves are crisp and slightly bitter, and most people use them to make raw salads (Settaluri et al., 2015). Since lettuce is generally eaten raw, more nutrients are retained compared to other vegetables that are cooked or processed (Kim et al., 2016). 


\section{Cress (Lepidium sativum Linn.)}

Garden cress (Lepidium sativum; family-Cruciferae) is a fast-growing, perennial edible plant, botanically related to mustard. It is grown worldwide and often used most typically as a garnish or as a leaf vegetable. Due to its peppery, tangy and pungent flavor and aroma garden cress leaves are regarded as a garnishing material or consumed in salads (Jain \& Grover, 2018). Hassan et al., (2012) Hassan et al., (2012) reported that the leaves are a great source of potassium $(1850.00 \mathrm{mg} / 100 \mathrm{~g})$, sodium $(141.13 \mathrm{wmg} / 100 \mathrm{~g})$ and magnesium $(160.60 \mathrm{mg} / 100$ $\mathrm{g})$. The calcium, iron, zinc and copper contents of leaves have been reported as 360 and 28.6 $\mathrm{mg} / 100 \mathrm{~g} 2.28$ and $0.39 \mathrm{mg} / 100 \mathrm{~g}$ respectively (Hassan et al., 2011). Garden cress helps to purify blood and stimulate appetite. It also helps to alleviate anemia due to its high iron content (Jain and Grover, 2018).

\section{Cabbage (Brassica oleracea var. capitata)}

Cabbage is assumed to have originated from the coast of the North Sea, the English channel and northern Mediterranean (Jongman \& Korsten, 2017). White cabbage is among the world's most commonly cultivated vegetables. It belongs to the genus Brassica and the mustard family, it is little expensive, though very nutritive, source of food, providing nutrients and health-promoting phytochemicals (Šamec et al., 2017). Due to its availability at local markets white cabbage stands out as an important source of phytonutrients in the human diet (Bjorkman et al., 2011). Cabbage is an excellent source of vitamin C and vitamin $\mathrm{K}$, containing more than $20 \%$ of the daily value for each of these nutrients per serving. Cabbage is also a good source of dietary fiber, vitamin B6 and folate, with no other nutrients having significant content per 100 gram serving (Settaluri et al., 2015).

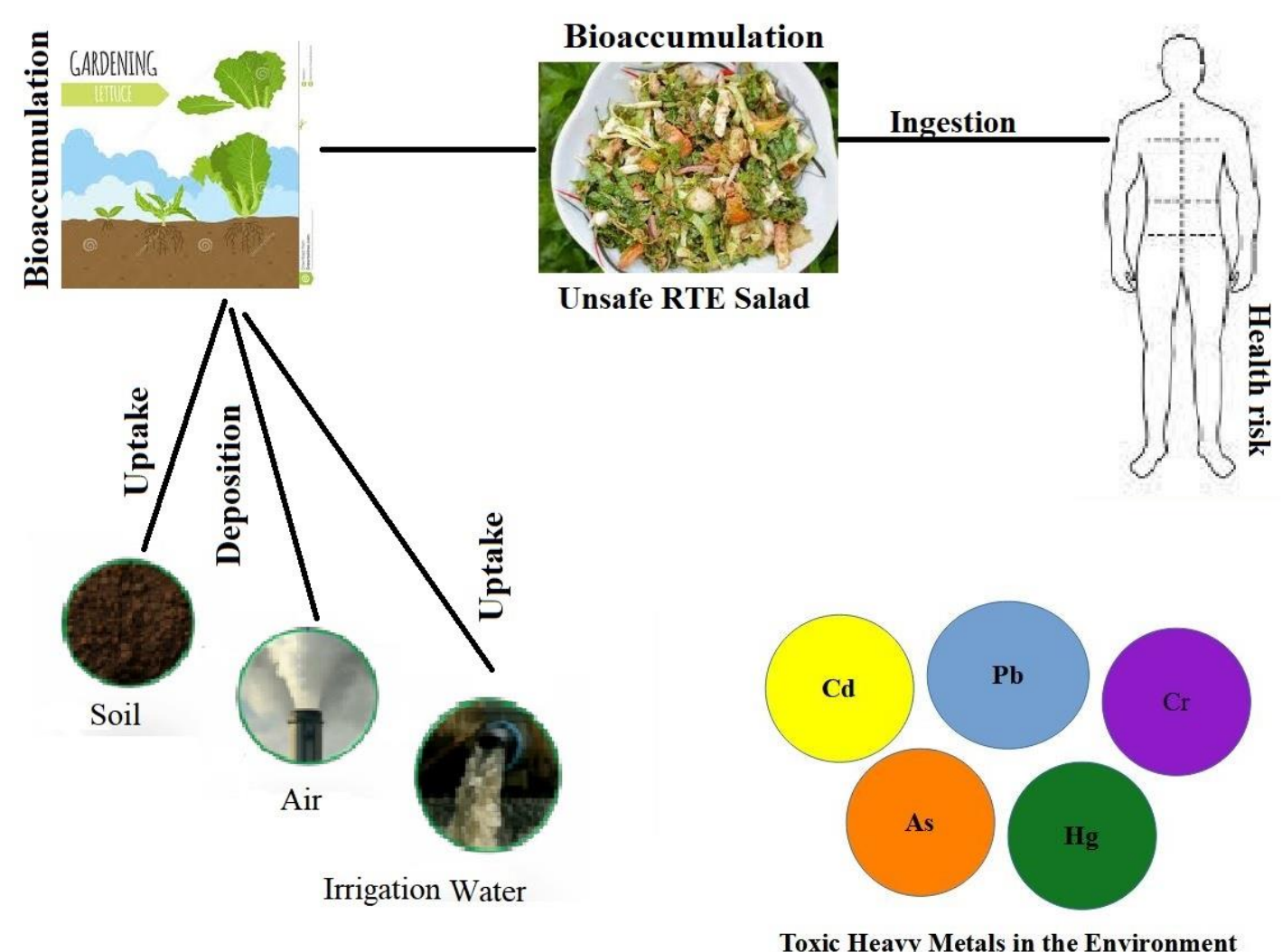

Figure 2: Accumulation of heavy metals in RTE salad

Source: Sandeep et al., 2019) 


\section{Heavy metals (HMs)}

Heavy metals are defined as naturally occurring metals having an atomic number greater than 20 and an elemental density greater than $5 \mathrm{~g} / \mathrm{cm}^{3}$ (Ali et al., 2018; Onakpa et al., 2018). In other words, HMs are generally used to describe chemical elements with a specific gravity that is at least 5 times the specific gravity of water; the specific gravity of water is 1 at $4^{\circ} \mathrm{C} / 39^{\circ} \mathrm{F}$ (Hannah et al., 2016; Nagajyoti et al., 2010). HMs include lead (Pb), cadmium (Cd), zinc ( $\mathrm{Zn})$, mercury $(\mathrm{Hg})$, arsenic $(\mathrm{As})$, silver $(\mathrm{Ag})$, chromium $(\mathrm{Cr})$, copper $(\mathrm{Cu})$, iron $(\mathrm{Fe})$, and platinum (Pt) (Onakpa et al., 2018). However, chemical properties of the heavy metals are the most influencing factors compared to their density.

They are an vital class of environmental pollutants ( Ali et al., 2018; Nagajyoti et al., 2010). These elements are released in air, water, and soils as a result of different geological and anthropogenic activities. Contamination of water resources by HMs is a critical environmental issue that adversely affects plants, animals, and human health (Ali et al., 2018).

The major path through which these HMs pollute the food chain in Nigeria is the soil, water, and other inorganic substances by the process of leaching and runoff while human exposure pathways to these HMs are ingestion, inhalation, and dermal (Ihedioha et al., 2017). Foods on sale in the open market place are at high risk of being contaminated by HMs (Nkwunonwo et al., 2020). Human contact to HMs through food, air, and water has increased intensely during the past century, as a result of different human activities such as industrialization, mining, irrigation, sludge application, used of agro-chemicals, and vehicular emission (Akhtar et al., 2021). Thus, the HMs pollution has become of great concern because of food safety issues, potential health risks, and its detrimental effects on soil ecosystems (Cherfi \& Cherfi, 2016; Manzoor et al., 2018).

The existence of HMs in floras is classified as non-essential and essential (Sandeep et al., 2019). All metals turn lethal to the living creature as soon as they exceed the acceptance limit. Zn, Fe, and $\mathrm{Cu}$ are necessary for plants and animals. Metals like $\mathrm{Fe}, \mathrm{Mo}, \mathrm{Cu}, \mathrm{Mn}$, and $\mathrm{Zn}$ are crucial heavy metals in flora and fauna as they play a role in physiological and biochemical functions. There are two main utilities of essential HMs: (a) Direct Contribution is an integral of numerous enzymes, (b) Contribution in a redox reaction (Mayuri et al., 2020; Nagajyoti et al., 2010; Sandeep et al., 2019). These essential trace metal nutrients take part in redox reactions, electron transfer and structural functions in nucleic acid metabolism (Nagajyoti et al., 2010).

Leafy vegetables, accumulate higher amounts of HMs because they take-in these metals in their leaves (Bagdatlioglu \& Nergiz, 2010; Garg et al., 2014) posing carcinogenic and noncarcinogenic health risks to humans (Ali et al., 2018). Vegetable crops take up HMs such as $\mathrm{Hg}, \mathrm{Pb}, \mathrm{Cd}, \mathrm{Zn}$, and $\mathrm{Cu}$ and accumulate them in their edible and inedible parts with several concentrations (Musa et al., 2017). HMs harmfulness in plants varies with plant species, specific metal, concentration, chemical form and soil composition and $\mathrm{pH}$, as many heavy metals are considered to be essential for plant growth (Nagajyoti et al., 2010). Consumption of HMs contaminated crops causes' great risk to human health. Long term intake of unsafe levels of HMs through foods may result in disruption of many biological and biochemical processes in humans (Ali et al., 2018). Therefore, to assure food quality different foreign and local regulatory bodies had laid down maximum permissible levels of toxic metals in different food items due to an increased awareness of the risk for these metals. Diffrent studies have been undertaken to monitor HMs concentration in edible vegetables (Garg et al., 2014). Copper $(\mathrm{Cu})$, iron $(\mathrm{Fe})$, manganese $(\mathrm{Mn})$, nickel $(\mathrm{Ni})$, and zinc $(\mathrm{Zn})$ are required by vegetables in trace quantities and in excess these metals which may become greatly harmful. However, nonessential metals, such as aluminum (Al), arsenic (As), cadmium (Cd), lead (Pb), and mercury 
$(\mathrm{Hg})$, are not required for normal biological function and may quickly lead to harmfulness (Manzoor et al., 2018).

\section{Essential heavy metals}

Necessary elements are those which are required by living organisms for different biochemical and physiological functions in the body. Examples of essential HMs include Mn, $\mathrm{Fe}, \mathrm{Co}, \mathrm{Cu}$, and $\mathrm{Zn}$ (Ali et al., 2018; Sandeep et al., 2019) which are necessary for maintaining good health throughout life. Some HMs such as $\mathrm{Cu}, \mathrm{Zn}, \mathrm{Mn}, \mathrm{Co}$ and Mo act as micronutrients for the growth of human beings when present in trace quantities (Ali \& Al-qahtani, 2012). Essential HMs are also possibly toxic if present in extra (Sandeep et al., 2019). Such elements like $\mathrm{Cu}$ and $\mathrm{Zn}$ are considered among the most toxic HMs in the environment. Long-term exposure to $\mathrm{Cu}$ has adverse effects on human health and can cause liver disease and severe neurological problems (Ali et al., 2018).

\section{Zinc (Zn)}

Zinc is a mineral of exceptional biologic and public health importance (Dias, 2012). Zinc is a component of a variety of enzymes, including the ribonucleic polymerases, alcohol dehydrogenase, carbonic anhydrase, and alkaline phosphatase in humans. Zinc is required to maintain the integrity of ribosome. It takes part in the formation of carbohydrates and catalyzes the oxidation processes in plants. Zinc also provides a structural role in many transcription factors and is a cofactor of RNA polymerase (Nagajyoti et al., 2010). Zinc deficiency affects about 2 billion people in the developing world and is associated with many diseases, the concentration of zinc in vegetables varies based on levels of the element in soil (Dias, 2012). Deficiency of zinc can result from inadequate dietary intake, impaired absorption, excessive excretion or inherited defects in zinc metabolism (Bagdatlioglu \& Nergiz, 2010).

\section{Iron (Fe)}

Iron is an essential element for humans. It is a constituent of haemoglobin, myoglobin and a number of enzymes, and as much as $30 \%$ of the body iron is found in storage forms such as ferritin and hemosiderin, in the spleen, liver, and bone marrow, and a small amount is associated with the blood transport protein transferrin (Shander et al., 2009). Iron deficiency results in anemia, which ranges from a fall in plasma ferritin with no functional impairment to severe iron deficiency characterized by small red blood cells with low hemoglobin concentrations (Bagdatlioglu \& Nergiz, 2010; Dias, 2012; Nagajyoti et al., 2010). Dark green leafy vegetables are among the good sources of iron. Most at risk of iron deficiency are infants, adolescent girls and pregnant women. Pregnant women are at special risk of low iron levels and are often advised to supplement their iron intake. Iron deficiency in infants can result in impaired learning ability and behavioural problems. It can also affect the immune system and cause weakness and fatigue (Dias, 2012).

\section{Chromium (Cr)}

$\mathrm{Cr}$ is an important element for the insulin activity and DNA transcription. However, an intake below $0.02 \mathrm{mg}$ per day could reduce cellular responses to insulin (Guerra et al., 2012). Chromium is one of the less common elements and does not occur naturally in elemental form, but only in compounds. It is mined as a primary ore product in the form of the mineral chromite $\left(\mathrm{FeCr}_{2} \mathrm{O}_{4}\right)$. Key sources of $\mathrm{Cr}$ impurity include releases from electroplating processes and the disposal of $\mathrm{Cr}$ containing wastes. Chromium (VI) is the form of $\mathrm{Cr}$ commonly found at contaminated sites. Chromium can also show in the +III oxidation state, depending on $\mathrm{pH}$ and redox conditions. Chromium (VI) is the dominant form of $\mathrm{Cr}$ in shallow aquifers where aerobic conditions exist (Saha et al., 2011). Chromium (VI) can be reduced to Cr (III) by soil 
organic matter (Raymond \& Felix, 2011) (Wuana \& Okieimen, 2011). Major Cr (VI) species include chromate $\left(\mathrm{CrO}_{4} 2^{-}\right)$and dichromate $\left(\mathrm{Cr}_{2} \mathrm{O}_{7}{ }^{2-}\right)$ which precipitate readily in the presence of metal cations (especially $\mathrm{Ba}^{2+}, \mathrm{Pb}^{2+}$, and $\mathrm{Ag}+$ ). Chromate and dichromate also adsorb on soil surfaces, especially iron and aluminum oxides. Chromium (III) is the dominant form of Cr at low pH (Musa et al., 2017).

\section{Copper $(\mathbf{C u})$}

Copper is compulsory for body pigmentation in summing to iron, for the maintenance of a healthy Central Nervous System, copper deficiency is characterized by anemia, neutropenia and skeletal abnormalities and is interrelated with the function of zinc and iron in the body (Bagdatlioglu \& Nergiz, 2010). Copper and Chromium are crucial elements but when take in excess, they cause toxicity. It should be noted that the threshold for the effects of copper on the gastrointestinal tract still leaves some uncertainty regarding the long-term effects of $\mathrm{Cu}$ on sensitive populations, such as carriers of gene for Wilson disease and other metabolic disorders of copper homeostasis (Nkwunonwo et al., 2020). Copper is an essential HM for higher plants and algae, particularly for photosynthesis. Because $\mathrm{Cu}$ can readily gain and lose an electron, it is a cofactor of oxidase, mono- and di-oxygenase (e.g., amine oxidases, ammonia monoxidase, ceruloplasmin, lysyl oxidase) and of enzymes involved in the elimination of superoxide radicals for example, superoxide dismutase and ascorbate oxidase (Nagajyoti et al., 2010). Copper is an essential micronutrient required in the growth of both plants and animals while in humans, it helps in the production of blood haemoglobin. High quantity intake of copper can cause anaemia, liver and kidney damage, and stomach and intestinal irritation in human. Copper normally occurs in drinking water from Copper pipes, as well as from additives designed to control algae growth (Musa et al., 2017).

\section{Non-essential heavy metals}

The poisonous elements such as cadium and lead are natural constituents of the earth's crust; they are adsorbed from the soil by plants and transferred further through the food chain. The extreme amount of these metals in food is associated with etiology of a number of diseases, especially with cardiovascular, kidney, nervous as well as bone diseases. Lead is well known for its toxicity and contrary effects on human health. Absorption of ingested lead may constitute a severe risk to public health. Some chronic effects of lead poisoning are colic, constipation and anemia (Bagdatlioglu \& Nergiz, 2010). High concentrations of $\mathrm{Cu}, \mathrm{Cd}$ and $\mathrm{Pb}$ in fruits and vegetables were related to high prevalence of upper gastrointestinal cancer (Ali \& Al-qahtani, 2012). Non-essential elements are those elements, which have no known biological function in the body. The four environmentally most hazardous heavy metals and metalloids, that is, $\mathrm{Cd}, \mathrm{Pb}, \mathrm{Hg}$, and As are generally regarded as non-essential elements (Ali et al., 2018). $\mathrm{Hg}, \mathrm{Pb}, \mathrm{Cd}$ and $\mathrm{Cr}$ are of great concern due to their toxicity to human health and other organism, whereas $\mathrm{Zn}$ and $\mathrm{Cu}$ are essential elements for plants and human (Musa et al., 2017). Lead, mercury and cadmium are called "the big three", on the toxicity list among various metal ions due to their major impact on the environment (Sandeep et al., 2019).

\section{Cadmium (Cd)}

Cadmium (Cd), a toxic heavy transition metal, belongs to group IIB of the periodic table and is present in soils, sediments, air and water at concentrations ranging from 0.1 to $1 \mathrm{mgkg}^{-1}$ (Huang et al., 2017). Cadmium has adverse effects on human health through accumulation in the human body resulting from occupational and non-occupational exposure. Occupational exposure mainly occurs though non-ferrous metal mining and smelting, production and processing of $\mathrm{Cd}$ containing compounds, and electronic waste recycling processes. For nonsmokers, diet and house dust are the main routes of $\mathrm{Cd}$ exposure. Following exposure, $\mathrm{Cd}$ is absorbed in various organs of the body, i.e. kidney, liver, lungs, testes, spleen, thymus, heart, 
epididymis, prostate, and salivary glands. Cadmium leads to the dysfunction of different organs and brings about multiple adverse effects on human health. Cadmium is introduced into the food chain through agarian soil. In general, metal concentrations are normally higher in roots than shoots, but in numerous leafy vegetables (e.g. lettuces and endives), Cd is stored in the leaves due to its high uptake and translocation (Carocci et al., 2015). These vegetables are considered as $\mathrm{Cd}$ accumulators and are taken up into the body a as part of the human diet (Huang et al., 2017). Cd is a hazardous element because it can be absorbed through the alimentary tract, penetrate through placenta during pregnancy, and damage membranes and DNA. Once in the human body, it may stay in the metabolism from sixteen to thirty three years and is connected to several health problems, such as renal damages and abnormal urinary excretion of proteins. Decrease in bone calcium concentrations and increase of urinary excretion. Calcium also been attributed to exposure to $\mathrm{Cd}$, eventually causing death (Guerra et al., 2012). It also affects reproduction and endocrine systems of women. Vegetables may contribute to about $70 \%$ of $\mathrm{Cd}$ intake by humans, varying according to the level of consumption (Guerra et al., 2012). The Commission of the European Communities and the Codex Alimentarius Commission (2001) set the Maximum Limit for Cadmium as $0.2 \mathrm{mg} / \mathrm{kg}$ for leafy vegetables and fresh herbs, $0.1 \mathrm{mg} / \mathrm{kg}$ for stem and root vegetables and $0.05 \mathrm{mg} / \mathrm{kg}$ for the remaining ungrouped vegetables. For lead, both organizations set the ML of 0.3 $\mathrm{mg} / \mathrm{kg}$ for brassicas, leafy vegetables and herbs, and $0.1 \mathrm{mg} / \mathrm{kg}$ for all remaining vegetables (Hannah et al., 2016). The use of agricultural inputs such as fertilizers, pesticides, and biosolids (sewage sludge), the disposal of industrial wastes or the deposition of atmospheric contaminants increases the total concentration of $\mathrm{Cd}$ in soils, and the bioavailability of this $\mathrm{Cd}$ determines whether plants' Cd uptake occurs to a significant degree (Musa et al., 2017). Ali et al., (2018) claimed that contact to Cd may cause kidney damage.

\section{Lead $(\mathbf{P b})$}

The toxic effects of $\mathrm{Pb}$ focus on many organs, such as liver, kidneys, spleen and lung, causing a range of biochemical defects. The nervous system of young one is particularly affected by the toxicity of this $\mathrm{HM}$. There is relationship between $\mathrm{Pb}$ in human body and the increase of blood pressure in adults (Almeida-Lopes et al., 2017). Although Pb effects are more relevant for children, calculations for risk assessment were made for adults and children (Guerra et al., 2012). Exposure to $\mathrm{HMs}$ like $\mathrm{Pb}$ and $\mathrm{Hg}$ may cause autoimmunity, a condition in which a person's immune system attacks its own cells. Autoimmunity can cause diseases of joints, such as: rheumatoid arthritis, and diseases of kidneys, circulatory system, nervous system, and damage to the fetal brain (Ali et al., 2018). Exposure to lead can result in a wide range of biological effects depending on the level and duration of exposure. Different effects occur over a wide range of doses, with the developing young and infants being more sensitive than adults. Lead poisoning, which is so severe as to cause evident illness, is now very rare. Lead performs no known essential function in the human body; it can merely do injury after uptake from food, air, or water (Wuana \& Okieimen, 2011). Higher concentrations of $\mathrm{Pb}$ are more likely to be found in leafy vegetables e.g., lettuce (Musa et al., 2017). Lead poisoning may result in headaches, irritability, abdominal pain, and nervous system disorders (Gall et al., 2015).

\section{Mercury (Hg)}

The main source of mercury is the Sulphide ore cinnabar, mercury (II) forms strong complexes with a variety of both inorganic and organic ligands, making it very soluble in oxidized aquatic systems (Silva \& Camilotti, 2014). Under anaerobic conditions, both organic and inorganic forms of $\mathrm{Hg}$ may be changed to alkylated forms by microbial activity, such as by sulfur reducing bacteria. Elemental mercury may also be formed under anaerobic conditions 
by demethylation of methylmercury, or by reduction of $\mathrm{Hg}$ (II). Acidic conditions $(\mathrm{pH}<4)$ also favour the formation of methyl mercury. It has been established medically that mercury is associated with kidney damage (Musa et al., 2017). Exposure to Hg may damage lungs and kidneys, as well as cause neurological and psychological problems such as changes in personality, restlessness, anxiety, sleep disturbance, and depression (Gall et al., 2015).

Table 1: Acceptable daily intake of different heavy metals

\begin{tabular}{lll}
\hline Heavy Metal & Tolerable Intake & Reference \\
\hline $\mathrm{As}$ & $2.1 \mu \mathrm{g} / \mathrm{kg} \mathrm{bw} /$ day & (Codex, 2011) \\
$\mathrm{Cd}$ & $0.83 \mu \mathrm{g} / \mathrm{kg}$ bw & (Codex, 2011) \\
$\mathrm{Cr}$ & $30-100 \mu \mathrm{g}$ daily intake & (Eisler, 2000; Langård and Costa, 2007) \\
$\mathrm{Pb}$ & $3.6 \mu \mathrm{g} / \mathrm{kg} \mathrm{bw} /$ day & (Codex, 2011) \\
$\mathrm{Hg}$ & $0.57 \mu \mathrm{g} / \mathrm{kg} \mathrm{bw} /$ day & (Codex, 2011) \\
$\mathrm{Ni}$ & $1.0 \mathrm{mg} / \mathrm{day}$ & US Institute of Medicine (2001) \\
$\mathrm{Co}$ & $5 \mu \mathrm{g} /$ day & (Lison, 2007) \\
$\mathrm{Cu}$ & 0.05 to $0.5 \mathrm{mg} / \mathrm{kg} \mathrm{bw} /$ day & (Codex, 2011) \\
$\mathrm{Zn}$ & $0.3-1 \mathrm{mg} / \mathrm{kg} \mathrm{bw} /$ day & (Codex, 2011) \\
\hline
\end{tabular}

Source: (Abdullahi et al., 2021)

Table 2: Important heavy metals and their health implications

\begin{tabular}{|c|c|c|c|}
\hline Heavy Metal & $\begin{array}{l}\text { Permissible } \\
\text { Level (mg/l) }\end{array}$ & Major Source & Toxic Effect \\
\hline Lead & 0.1 & $\begin{array}{l}\text { Mining, Paint, Pigment, } \\
\text { electroplating, manufacturing of } \\
\text { batteries, burning of coal }\end{array}$ & $\begin{array}{l}\text { Anemia, Brain Damage, anorexia, malaise, } \\
\text { loss of appetite, Liver, Kidney, } \\
\text { gastrointestinal damage, mental retardation } \\
\text { in children }\end{array}$ \\
\hline Copper & 0.1 & $\begin{array}{l}\text { Plating, Copper Polishing, Paint, } \\
\text { Printing Operations }\end{array}$ & $\begin{array}{l}\text { Neurotoxicity and acute toxicity, dizziness, } \\
\text { diarrhea. }\end{array}$ \\
\hline Cadmium & 0.06 & $\begin{array}{l}\text { Plastic, Welding, pesticide, } \\
\text { fertilizer, mining, refining }\end{array}$ & $\begin{array}{l}\text { Kidney damage, bronchitis, } \\
\text { Gastrointestinal disorder, bone marrow } \\
\text { cancer, lung insufficiency, hypertension, } \\
\text { Itai-Itai disease, weight loss }\end{array}$ \\
\hline Zinc & 1.5 & $\begin{array}{lcc}\text { Mining, refineries, } & \text { Brass } \\
\text { manufacturing, Plumbing } & \\
\end{array}$ & $\begin{array}{l}\text { Causes short term Metal-fume fever, } \\
\text { gastrointestinal distress }\end{array}$ \\
\hline Mercury & 0.01 & $\begin{array}{l}\text { Batteries, Paper industry, paint } \\
\text { industries, Mining }\end{array}$ & $\begin{array}{l}\text { Damage to nervous system, protoplasm } \\
\text { poisoning corrosive to skin, eyes, muscles, } \\
\text { dermatitis, Kidney damage }\end{array}$ \\
\hline Nickel & 0.2 & $\begin{array}{l}\text { Porcelains enameling, non-ferrous } \\
\text { metal, paint formulation, } \\
\text { electroplating }\end{array}$ & $\begin{array}{l}\text { Chronic Bronchitis, reduced lung function, } \\
\text { lung cancer }\end{array}$ \\
\hline Arsenic & 0.02 & $\begin{array}{l}\text { Smelting, Mining, } \\
\text { sedimentation, pesticides }\end{array}$ & $\begin{array}{l}\text { Bronchitis, dermatitis, bone marrow } \\
\text { depression, haemolysis, hepatomegaly }\end{array}$ \\
\hline
\end{tabular}

Source: (Sandeep et al., 2019) 


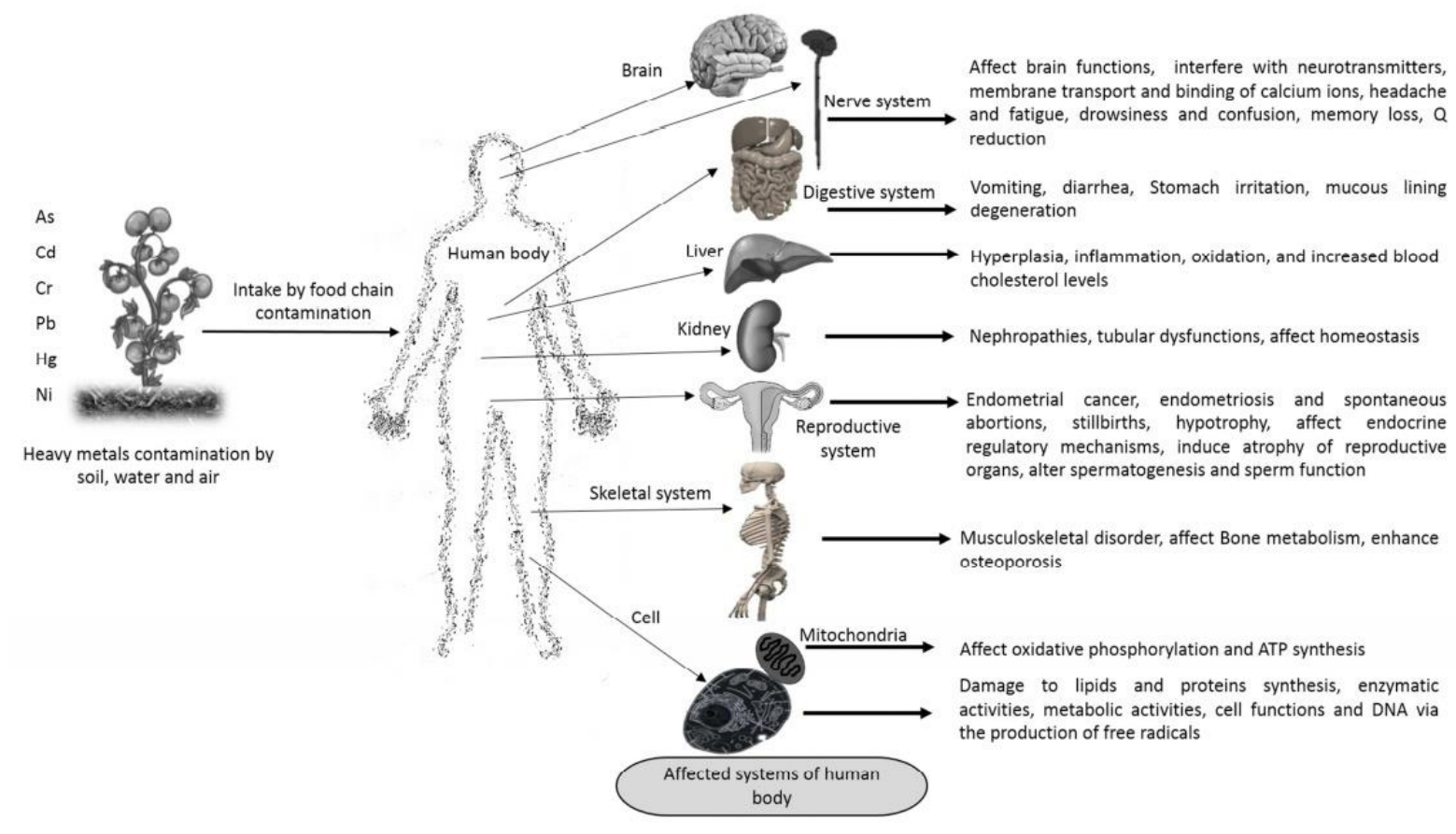

Figure 2: Health effect of heavy metals on human

(Source: Sandeep et al., 2019)

\section{Sources of Heavy Metals}

There are many sources of HMs in the environment such as (1) natural sources, (2) agricultural sources, (3) industrial sources, (4) domestic effluent (5) atmospheric sources and (5) other sources (Sandeep et al., 2019; Nagajyoti et al., 2010).

\section{Natural sources of heavy metals}

The main important natural sources for HMs introduction into soils are weathering of rocks, erosion and volcanic activity and application of biosolids (e.g., livestock manures, composts, and municipal sewage sludge). The composition and concentration of heavy metals depend on the rock type and environmental conditions, activating the weathering process. The geologic plant materials generally have high concentrations of $\mathrm{Cr}, \mathrm{Mn}, \mathrm{Co}, \mathrm{Ni}, \mathrm{Cu}, \mathrm{Zn}, \mathrm{Cd}, \mathrm{Sn}$, $\mathrm{Hg}$ and $\mathrm{Pb}$. However, class-wise the heavy metal concentrations vary within the rocks. Soil formation takes place mostly from sedimentary rock but is only a small source of heavy metals, since it is not generally or easily weathered. However, several igneous rocks such as olivine, augite and hornblende add considerable amounts of $\mathrm{Mn}, \mathrm{Co}, \mathrm{Ni}, \mathrm{Cu}$ and $\mathrm{Zn}$ to the soils. Within the class of sedimentary rocks, shale has highest concentrations of $\mathrm{Cr}, \mathrm{Mn}, \mathrm{Co}$, $\mathrm{Ni}, \mathrm{Cu}, \mathrm{Zn}, \mathrm{Cd}, \mathrm{Sn}, \mathrm{Hg}$ and $\mathrm{Pb}$ followed by limestone and sand stone (Sandeep et al., 2019). Volcanoes have been reported to emit high levels of $\mathrm{Al}, \mathrm{Zn}, \mathrm{Mn}, \mathrm{Pb}, \mathrm{Ni}, \mathrm{Cu}$ and $\mathrm{Hg}$ along with toxic and destructive gases (Nagajyoti et al., 2010; Sandeep et al., 2019).

\section{Agricultural sources of heavy metals}

Sources of HMs in soil are evrywhere in the environment due to both natural as well as human induced sources found in soils (Rahimi et al., 2017; Ratul et al., 2018; Kumar et al., 2019). The inorganic and organic fertilizers are the most vital sources of HMs to agricultural soil and these include liming, sewage sludge, irrigation waters and pesticides (Gall et al., 2015; Sandeep et al., 2019). Others, particularly fungicides, inorganic fertilizers and phosphate fertilizers have variable levels of $\mathrm{Cd}, \mathrm{Cr}, \mathrm{Ni}, \mathrm{Pb}$ and $\mathrm{Zn}$ depending on their sources. Cadmium is of particular concern in plants since it accumulates in leaves at very high levels, which may be consumed 
by animals or human being. Animal manure enriches the soil by the addition of $\mathrm{Mn}, \mathrm{Zn}, \mathrm{Cu}$ and $\mathrm{Co}$ and sewage sludge by $\mathrm{Zn}, \mathrm{Cr}, \mathrm{Pb}, \mathrm{Ni}, \mathrm{Cd}$ and $\mathrm{Cu}$. Liming increases the HMs levels in the soil more than the nitrate fertilizers and compost refuse (Gill, 2014).

Sewage sludge is one of the most important sources of heavy metal impurity to the soil. Several heavy metal-based pesticides are used to control the diseases of grain and fruit crops and vegetables and are sources of heavy metal pollution to the soil ( Nagajyoti et al., 2010; Sandeep et al., 2019).

\section{Industrial sources of Heavy Metals}

Industrial sources of heavy metals include mining, refinement and recycling of metals. Mining operation emits different heavy metals such as $\mathrm{As}, \mathrm{Cd}, \mathrm{Fe}$, depending on the type of mining. Vapour form of heavy metals such as $\mathrm{As}, \mathrm{Cd}, \mathrm{Cu}, \mathrm{Pb}, \mathrm{Sn}$ and $\mathrm{Zn}$ combine with water in the atmosphere to form aerosols. These may be either dispersed by wind (dry deposition) or precipitated in rainfall (wet deposition) causing contamination of soil or water bodies (Sandeep et al., 2019). Contamination of soil and water bodies can also occur through runoff from erosion of mine wastes, dusts produced during the transport of crude ores, corrosion of metals and leaching of heavy metals to soil and ground water. Soil contamination of heavy metals occurs due to different types of processing in refineries (Nagajyoti et al., 2010). Other industrial sources include processing of plastics, textiles, microelectronics, wood preservation and paper processing (Nagajyoti et al., 2010; Sandeep et al., 2019).

\section{Domestic Effluents}

These waste waters possibly constitute the largest single source of elevated metal values in rivers and lakes. Household effluents may consist of (a) untreated mechanically and treated waste waters (b) substances which have passed through the filters of biological treatment plants (c) waste substances passed over sewage outfalls and discharged to receiving water bodies often end up into the sea from coastal residential areas (Sandeep et al., 2019). The apppliation of detergents creates a possible pollution hazard, since common house hold detergent products can affect the water quality. Other sources of HMs include refuse incineration, landfills and transportation (automobiles, diesel-powered vehicles and aircraft) (Gill, 2014). Two main human sources that pollute the soil are fly ash produced due to coal burning and the corrosion of commercial waste products, which add $\mathrm{Cr}, \mathrm{Cu}, \mathrm{Pb}$ and galvanized metals (primarily Zn) into the environment. Coal burning adds HMs such as Cd, $\mathrm{Hg}$, Mn, Ni, Al, Fe and Ti into the soils ( Nagajyoti et al., 2010; Sandeep et al., 2019).

\section{Atmospheric sources}

Natural and man-made processes have been shown to result in metal containing airborne particulates. Depending on prevailing climatic conditions, these particulates may become wind-blown over great distances; nonetheless, they are subjected to the fate that they are ultimately returned to the lithosphere as precipitations by rain or snowfall. Additional sources of atmospheric metal enrichment, such as the high temperature anthropogenic sources, are of special importance on a global scale (Nagajyoti et al., 2010).

\section{Heavy metals in vegetable}

Heavy metal contamination of vegetables cannot be underrated as these foodstuffs are significant components of human diet (Ali \& Al-qahtani, 2012). Air pollution may pose a risk to post-harvest vegetables during transportation and marketing, causing elevated levels of HMs in vegetables (Ali \& Al-qahtani, 2012). When vegetables are grown in affected areas and by irrigating waste water with heavy metals, their concentration increases near the root zone and plant system absorbs the nutrients along with HMs, these absorbed heavy metals get 
accumulated in the plant parts, usually they get accumulated more in root part and leaves (Hannah et al., 2016; Kalali et al., 2011). Hence many researchers showed that accumulation of HMs are documented high in leafy vegetables followed by root crops (Singh \& Singh, 2014).

Some of these heavy metals i.e. As, $\mathrm{Cd}, \mathrm{Hg}$, $\mathrm{Pb}$ or Se are not vital for plants growth, since they do not implement any known physiological function in plants. Others such as $\mathrm{Co}, \mathrm{Cu}, \mathrm{Fe}, \mathrm{Mn}$, $\mathrm{Mo}, \mathrm{Ni}$ and $\mathrm{Zn}$ are essential elements required for normal growth and metabolism of plants but these elements can easily lead to poisoning when their concentration is greater than the optimal values (Rascio \& Izzo, 2011; Sandeep et al., 2019).

Leafy vegetables accumulate more HMs and it is reported that vegetables may act as a medium for carrying poisonous substances like pesticide residues and heavy metals to human bodies that can cause different disorders among consumers (Manzoor et al., 2018). Evidence shows that vegetables and other food crops consumed in Nigeria are contaminated by heavy metals, and this is associated with adverse health issues, such as cancer, which is currently on the rise in Nigeria (Onakpa et al., 2018).

Leblebici \& Kar (2020) investigated the accumulation of HMs in five different leafy green vegetables grown in 10 different agricultural lands in the province of Nevşehir, Turkey. According to their accumulation in the vegetables, the detected heavy metal concentrations were listed as $\mathrm{Mn}>\mathrm{Zn}>\mathrm{Cu}>\mathrm{Ni}>\mathrm{As}>\mathrm{Cd}$. The estimated daily intake amount of the heavy metals was also found to be higher than the limits determined by FAO/WHO. The level of $\mathrm{Pb}$ and $\mathrm{Cr}$ exceeded the permissible limits in $44 \%$ of the analysed vegetable samples in the study conducted in Brazil (Guerra et al., 2012). Hannah et al., (2016) investigated six HMs (Pb, Cr, $\mathrm{Zn}, \mathrm{Cd}, \mathrm{Ni}$ and $\mathrm{Cu}$ ) accumulation in five popular leafy vegetables obtained from Four Market in Lagos Metropolis, Nigeria. The study shows the range of heavy metals content in vegetables across the markets; $\mathrm{Cd}(0.05-0.20 \mathrm{mg} / \mathrm{kg}) ; \mathrm{Pb}(0.34-5.44 \mathrm{mg} / \mathrm{kg}), \mathrm{Zn}(4.21-20.80 \mathrm{mg} / \mathrm{kg})$, $\mathrm{Cr}(0.25-1.51 \mathrm{mg} / \mathrm{kg}), \mathrm{Ni}(0.13-2.91 \mathrm{mg} / \mathrm{kg})$ and $\mathrm{Cu}(2.34-14.08 \mathrm{mg} / \mathrm{kg})$.

\section{How Heavy Metals are transported into the plants from soil}

Metal accessibility and movement in the rhizosphere is influenced by root exudates and microorganisms. It is conveyed by mass flow in plants. Transport of metal ions across root cellular membrane permits the access of metals into plant tissues. Metals are first taken into apoplast, a free intercellular space directed towards the xylem of the roots. HMs is trans located apoplastically into plant tissue due to continuum of root epidermis and cortex. The metals in root cells have to cross the endodermis and casparian strip to reach the xylem (Fahr et al., 2013; Sandeep et al., 2019). The cell walls of the endodermis and casparian strip act as a barrier for apoplastic diffusion into the vascular system. For root- shoot translocation of metals, metal transporters carry metal ions from root symplast into xylem apoplast and are probably driven by transpiration pump. Physiological concentrations of heavy metals in the plant cell are regulated by tonoplast as well as metal transporters on the plasma membrane (Song et al., 2016). Different classes of membrane proteins are known to involve in uptake of metals in plants, but still, there is a lacuna in understanding the molecular level transport of HMs across plant membranes (Sandeep et al., 2019; Song et al., 2016). Therefore, a complete knowledge of transport processes in plants is crucial to create transgenic plants that can accumulate specific metals to improve the process of soil decontamination and remediation (Sandeep et al., 2019). 


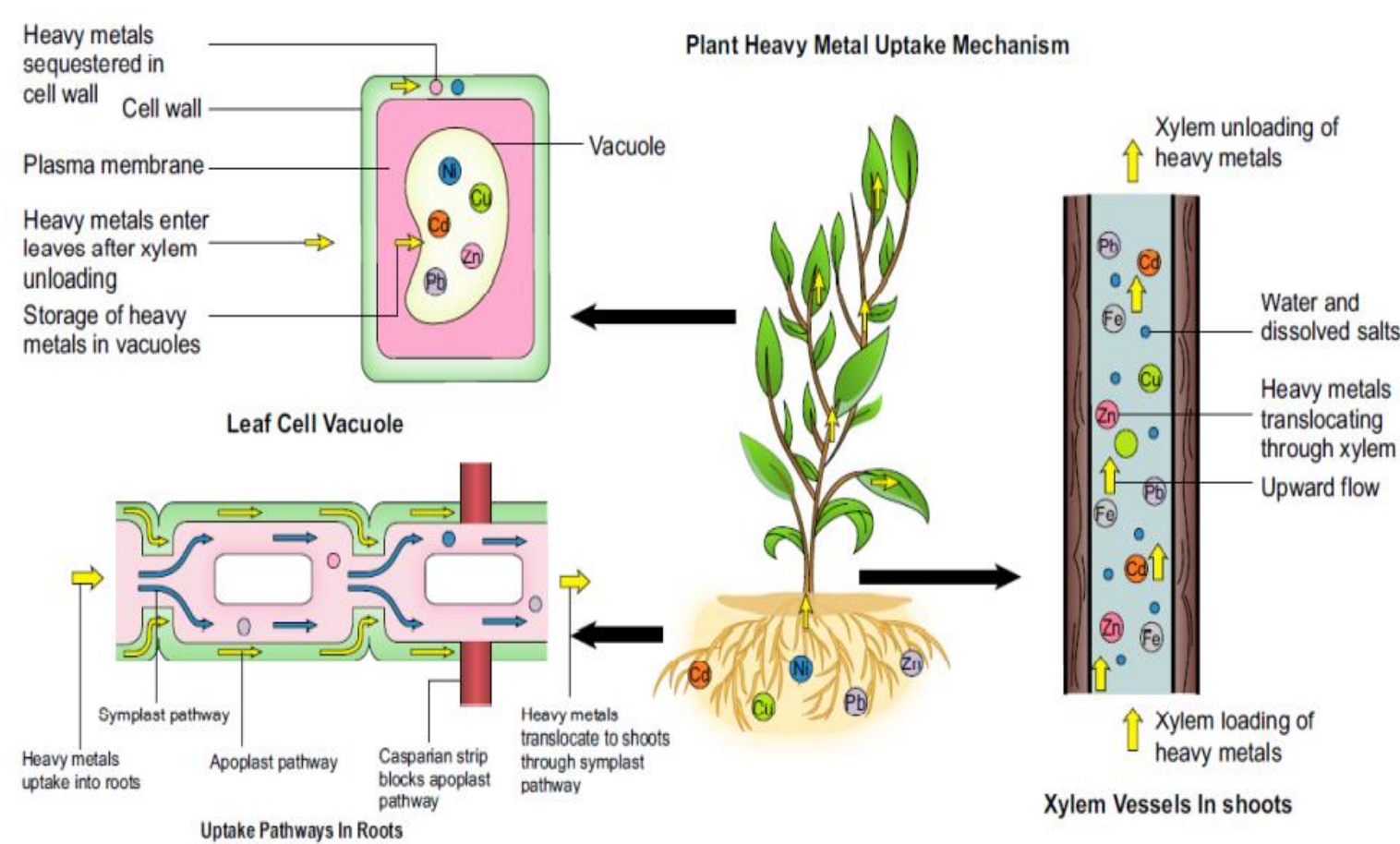

Figure 3: The process involved in the uptake of heavy metals. Source: (Ghori et al., 2016; Sandeep et al., 2019).

\section{CONCLUSION}

Presently, intake of salads has enlarged in developing countries including Nigeria due to changing lifestyle pattern and awareness on better nutrition and functional foods. Vegetable salads are vital part of a nutritious and healthy worldwide. This food is popular due to their convenience and acceptance by consumers; they also guarantee food security for rural and urban population and also serves as a source of income for hawkers. In contrast, exposure to heavy metals by consumption of contaminated vegetables and its toxicity is a serious health concern. However, limited numbers of studies are found to assess the permissible limits of HMs in vegetable. Thus, strategy and policy are required to control the limits of HMs accumulation in vegetables.

\section{REFERENCES}

Abakari, G., Cobbina, S. J., \& Yeleliere, E. (2018). Microbial quality of ready-to-eat vegetable salads vended in the central business district of Tamale, Ghana. International Journal of Food Contamination, 5(3), 3-9.

Abdullahi, N., Igwe, E. C., \& Dandago, M. A. (2021). Heavy metals contamination sources in Kano ( Nigeria ) and their concentrations along Jakara River and its agricultural produce. Moroccan Journal of Agricultural Sciences, 2(2), 106-113.

Ahmad, S., Ahmad, M., Maqbool, M., Dar, B. N., Greiner, R., \& Roohinejad, S. (2018).

Microbiological contamination of ready-to-eat vegetable salads in developing countries and potential solutions in the supply chain to control microbial pathogens. Food Control, 85, 235-244. https:// doi.org/10.1016/j.foodcont.2017.10.006

Ajayeoba, T. A., Atanda, O. O., Obadina, A. O., Bankole, M. O., \& Adelowo, O. O. (2015).

The incidence and distribution of Listeria monocytogenes in ready- to- eat vegetables in South- Western Nigeria. Food Science \& Nutrition, 4(1), 59-66. https://doi.org/10.1002/fsn3.263

Akhtar, N., Syakir Ishak, M. I., Bhawani, S. A., \& Umar, K. (2021). Various Natural and 
Anthropogenic Factors Responsible for Water Quality Degradation: A Review. Water, 13(19), 2660. https://doi.org/10.3390/w13192660

Ali, H., Khan, E., \& Ali, H. (2018). Human and Ecological Risk Assessment : An International Trophic transfer, bioaccumulation, and biomagnification of non-essential hazardous heavy metals and metalloids in food chains / webs - Concepts and implications for wildlife and human health webs - . Human and Ecological Risk Assessment, 0(0), 1-24. https://doi.org/10.1080/10807039.2018.1469398

Ali, M. H. H., \& Al-qahtani, K. M. (2012). Assessment of some heavy metals in vegetables , cereals and fruits in Saudi Arabian markets. The Egyptian Journal of Aquatic Research, 38(1), 31-37. https://doi.org/10.1016/j.ejar.2012.08.002

Almeida Lopes, A. C. B. De, Silbergeld, E. K., Navas-Acien, A., Zamoiski, R., Martins, A. D. C., Camargo, A. E. I., Urbano, M. R., Mesas, A. E., \& Paoliello, M. M. B. (2017). Association between blood lead and blood pressure: A population-based study in Brazilian adults. Environmental Health: A Global Access Science Source, 16(1), 1-10. https://doi.org/10.1186/s12940-017-0233-5

Amissah-reynolds, P. K., Yar, D. D., Gyamerah, I., Apenteng, O. Y., \& Sakyi, S. (2020). Fresh Vegetables and Ready-to-eat Salads: Sources of Parasitic Zoonoses in MampongAshanti , Ghana. European Journal of Nutrition \& Food Safety, 12(2), 47-55. https://doi.org/10.9734/EJNFS/2020/v12i230192

Bagdatlioglu, N., \& Nergiz, C. (2010). Heavy metal levels in leafy vegetables and some selected fruits. Journal of Consumer Protection and Food Safety, 5, 421-428. https://doi.org/10.1007/s00003-010-0594-y

Caponigro, V., Ventura, M., Chiancone, I., Amato, L., Parente, E., \& Piro, F. (2010). Variation of microbial load and visual quality of ready-to-eat salads by vegetable type, season , processor and retailer. Food Microbiology, 27(8), 1071-1077. https:// doi.org/10.1016/j.fm.2010.07.011

Carocci, A., Catalano, A., Lauria, G., Sinicropi, M. S., \& Genchi, G. (2015). Brief History of the Development of the Transfusion Service. How to Recruit Voluntary Donors in the Third World?, 238(December), 22-28. https:// doi.org/10.1007/398

Castro-rosas, J., Cerna-cortés, J. F., Méndez-reyes, E., Lopez-hernandez, D., Gómez-aldapa, C. A., \& Estrada-garcia, T. (2012). Presence of faecal coliforms, Escherichia coli and diarrheagenic $\mathrm{E}$. coli pathotypes in ready-to-eat salads, from an area where crops are irrigated with untreated sewage water. International Journal of Food Microbiology, 156(2), 176-180. https:// doi.org/10.1016/j.ijfoodmicro.2012.03.025

Cherfi, A., \& Cherfi, M. (2016). Risk assessment of heavy metals via consumption of vegetables collected from different supermarkets in La Rochelle, France. Environ Monit Assess, 188(136), 1-10. https://doi.org/10.1007/s10661-016-5140-7

Dan, S., Qiang, H., Zhaonan, D., \& Zhengquan, H. (2014). Genetic transformation of lettuce ( Lactuca sativa ): A review. 13(16), 1686-1693. https://doi.org/10.5897/AJB2014.13651

Dias, J. S. (2012). Major Classes of Phytonutriceuticals in Vegetables and Health Benefits : A Review. Journal of Nutritional Therapeutics, 1, 31-62.

e Silva, A. R. B., \& Camilotti VIII, F. (2014). Risks of Heavy Metals Contamination of SoilPant System by Land Application of Sewage Sludge: A Review with Data from Brazil. Environmental Risk Assessment of Soil Contamination, 874-908. https:// doi.org/10.5772/58384

Fahr, M., Laplaze, L., Bendaou, N., Hocher, V., El Mzibri, M., Bogusz, D., \& Smouni, A. (2013). Effect of lead on root growth. Frontiers in Plant Science, 4(JUN), 1-8. https://doi.org/10.3389/fpls.2013.00175

Gall, J. E., Boyd, R. S., \& Rajakaruna, N. (2015). Transfer of heavy metals through terrestrial food webs: a review. Environmental Monitoring and Assessment, 187(4).

https://doi.org/10.1007/s10661-015-4436-3 
Garg, V. K., Yadav, P., Mor, S., Singh, B., \& Pulhani, V. (2014). Heavy metals bioconcentration from soil to vegetables and assessment of health risk caused by their ingestion. Biological Trace Element Research, 157(3), 256-265. https://doi.org/10.1007/s12011-014-9892-z

Gil, Maria I., Selma, M. V., Suslow, T., Jacxsens, L., Uyttendaele, M., \& Allende, A. (2015). Pre- and Postharvest Preventive Measures and Intervention Strategies to Control Microbial Food Safety Hazards of Fresh Leafy Vegetables. Critical Reviews in Food Science and Nutrition, 55(4), 453-468. https:/ / doi.org/10.1080/10408398.2012.657808

Gil, María I, Allende, A., \& Castro-ib, I. (2017). Ready-to-eat vegetables : Current problems and potential solutions to reduce microbial risk in the production chain n. LWT - Food Science and Technology 85, 85, 284-292. https:/ / doi.org/10.1016/j.lwt.2016.11.073

Gill, M. (2014). Heavy metal stress in plants: a review. International Journal of Advanced Research, 2(6), 1043-1055.

Giusti, M. De, Aurigemma, C., Marinelli, L., Tufi, D., Medici, D. De, Pasquale, S. Di, \& Vito, C. De. (2010). The evaluation of the microbial safety of fresh ready-to-eat vegetables produced by different technologies in Italy. Journal of Applied Microbiology, 109, 9961006. https:// doi.org/10.1111/j.1365-2672.2010.04727.x

Guerra, F., Trevizam, A. R., Muraoka, T., Marcante, N. C., \& Canniatti-brazaca, S. G. (2012). Heavy metals in vegetables and potential risk for human health. Scientia Agricola, 69(1), 54-60.

Hannah, A., Longinus, K., Olatunde, M., \& Alex, A. (2016). Potential Human Health Risk Assessment of Heavy Metals Intake via Consumption of some Leafy Vegetables obtained from Four Market in Lagos Metropolis , Nigeria. J. Appl. Sci. Environ. Manage, 20(3), 530-539.

Hassan, L., Hassan, S., Hashim, T., Umar, K., \& Sani, N. (2012). Determination of Nutritive Values of Garden Cress (Lepidium sativum L.) Leaves. Bayero Journal of Pure and Applied Sciences, 4(2), 18-23. https:/ / doi.org/10.4314/ bajopas.v4i2.4

Huang, Y., He, C., Shen, C., Guo, J., Mubeen, S., Yuan, J., \& Yang, Z. (2017). Toxicity of cadmium and its health risks from leafy vegetable consumption. Food $\mathcal{E}$ Function. https://doi.org/10.1039/c6fo01580h

Thedioha, J. N., Ukoha, P. O., \& Ekere, N. R. (2017). Ecological and human health risk assessment of heavy metal contamination in soil of a municipal solid waste dump in Uyo, Nigeria. Environmental Geochemistry and Health, 39(3), 497-515. https://doi.org/10.1007/s10653-016-9830-4

Jain, T., \& Grover, K. (2018). A Comprehensive Review on the Nutritional and Nutraceutical Aspects of Garden Cress (Lepidium sativum Linn.). Proceedings of the National Academy of Sciences India Section B - Biological Sciences, 88(3), 829-836. https://doi.org/10.1007/s40011-016-0775-2

Jongman, M., \& Korsten, L. (2017). Irrigation water quality and microbial safety of leafy greens in different vegetable production systems: A review. Food Reviews International, 34(4), 308-328. https:/ / doi.org/10.1080/87559129.2017.1289385

Kim, M. J., Moon, Y., Tou, J. C., Mou, B., \& Waterland, N. L. (2016). Nutritional value, bioactive compounds and health benefits of lettuce (Lactuca sativa L.). Journal of Food Composition and Analysis, 49, 19-34. https:// doi.org/10.1016/j.jfca.2016.03.004

Kumar, S., Prasad, S., Yadav, K. K., Shrivastava, M., Gupta, N., Nagar, S., Bach, Q. V., Kamyab, H., Khan, S. A., Yadav, S., \& Malav, L. C. (2019). Hazardous heavy metals contamination of vegetables and food chain: Role of sustainable remediation approaches - A review. Environmental Research, 179, 108792. https://doi.org/10.1016/j.envres.2019.108792

Leblebici, Z., \& Kar, M. (2020). Assessment of the Heavy Metal Accumulation of Various Green Vegetables Grown in Nev ş ehir and their Risks Human Health. Environ Monit 
Assess, 192, 483

Manzoor, J., Sharma, M., \& Wani, K. A. (2018). Heavy metals in vegetables and their impact on the nutrient quality of vegetables: A review. Journal of Plant Nutrition, 41(13), 17441763. https:/ / doi.org/10.1080/01904167.2018.1462382

Mayuri, K., Tripathy, D. B., Bhati, K., Gupta, A., \& Sharma, S. (2020). THE LANDSCAPE ON THE METAL ANALYSIS IN GREEN VEGETABLES: A REVIEW. Journal of Natural Remedies, 21(8), : 0972-5547.

Mogren, L., Windstam, S., Boqvist, S., Vågsholm, I., Söderqvist, K., Rosberg, A. K., Lindén, J., Mulaosmanovic, E., Karlsson, M., Uhlig, E., Håkansson, A., \& Alsanius, B. (2018). The hurdle approach-A holistic concept for controlling food safety risks associated with pathogenic bacterial contamination of leafy green vegetables. A review. Frontiers in Microbiology, 9(AUG), 1-20. https:// doi.org/10.3389/fmicb.2018.01965

Musa, J. J., Mustapha, H. I., Bala, J. D., Ibrahim, Y. Y., Akos, M. P., Daniel, E. S., Oguche, F. M., \& Kuti, A. (2017). HEAVY METALS IN AGRICULTURAL SOILS IN NIGERIA: A REVIEW J. Arid Zone Journal of Engineering, Technology and Environment, 13(5), 593-603.

Nagajyoti, P. C., Lee, K. D., \& Sreekanth, T. V. M. (2010). Heavy metals, occurrence and toxicity for plants: A review. Environmental Chemistry Letters, 8(3), 199-216. https://doi.org/10.1007/s10311-010-0297-8

Nkwunonwo, U. C., Odika, P. O., \& Onyia, N. I. (2020). A Review of the Health Implications of Heavy Metals in Food Chain in Nigeria. The Scientific World Journal, 1-11.

Onakpa, M. M., Njan, A. A., \& Kalu, O. C. (2018). A review of heavy metal contamination of food crops in Nigeria. Annals of Global Health, 84(3), 488-494. https://doi.org/10.29024/aogh.2314

Sabbithi, A., Kumar, R. N., Kashinath, L., Bhaskar, V., \& Rao, V. S. (2014). Microbiological Quality of Salads Served along with Street Foods of Hyderabad, India. 2014.

Saha, R., Nandi, R., \& Saha, B. (2011). Sources and toxicity of hexavalent chromium. Journal of Coordination Chemistry, 64(10), 1782-1806. https:// doi.org/10.1080/00958972.2011.583646

Šamec, D., Pavlović, I., \& Salopek-Sondi, B. (2017). White cabbage (Brassica oleracea var. capitata f. alba): botanical, phytochemical and pharmacological overview. Phytochemistry Reviews, 16(1), 117-135. https:// doi.org/10.1007/s11101-016-9454-4

Sandeep, G., Vijayalatha, K. R., \& Anitha, T. (2019). Heavy metals and its impact in vegetable crops. International Journal of Chemical Studies, 7(1), 1612-1621. http://www.chemijournal.com/archives/2019/vol7issue1/PartAB/7-1-229-742.pdf

Settaluri, V. S., Al-Mamari, K. M. K., Al-Balushi, S. I. M., Al-Risi, M. K. Z., \& Ali, M. B. (2015). Review of Biochemical and Nutritional Constituents in Different Green Leafy Vegetables in Oman. Food and Nutrition Sciences, 06(09), 765-769. https://doi.org/10.4236/fns.2015.69079

Shander, A., Cappellini, M. D., \& Goodnough, L. T. (2009). Iron overload and toxicity: The hidden risk of multiple blood transfusions. Vox Sanguinis, 97(3), 185-197. https://doi.org/10.1111/j.1423-0410.2009.01207.x

Song, Y., Jin, L., \& Wang, X. (2016). Cadmium absorption and transportation pathways in plants. 6514(July). https://doi.org/10.1080/15226514.2016.1207598

Tatsika, S., Karamanoli, K., \& Karayanni, H. (2019). Metagenomic Characterization of Bacterial Communities on Ready-to-Eat Vegetables and Effects of Household Washing on their Diversity and Composition. Pathogens, 8(37).

https://doi.org/10.3390/pathogens8010037

Tirpanalan, Ö., Zunabovic, M., Domig, K. J., \& Kneifel, W. (2011). Mini review: Antimicrobial strategies in the production of fresh-cut lettuce products. Science against Microbial Pathogens: Communicating Current Research and Technological Advances, January, 176-188. http://www.formatex.info/microbiology3/book/176-188.pdf 
Varzakas, T. H., \& Arvanitoyannis, I. S. (2008). Original article Application of ISO22000 and comparison to HACCP for processing of ready to eat vegetables : Part I. International Journal of Food Science and Technology 2008, 43, 1729-1741.

https://doi.org/10.1111/j.1365-2621.2007.01675.x

Wuana, R. A., \& Okieimen, F. E. (2011). Heavy Metals in Contaminated Soils: A Review of Sources, Chemistry, Risks and Best Available Strategies for Remediation. ISRN Ecology, 2011, 1-20. https:// doi.org/10.5402/2011/402647 